\title{
Institutional investors in Russia: problems and prospects
}

\author{
Valery Salygin ${ }^{1}$, Irina Yarygina ${ }^{1, *}$, and Vladimir Smirnov ${ }^{2}$ \\ ${ }^{1}$ Moscow State Institute of International Relations, Moscow, Russia \\ ${ }^{2}$ Financial University under the Government of the Russian federation, Moscow, Russia
}

\begin{abstract}
The objective reasons for assessing the role of institutional investors as valuable participants of the Russian financial market and forecast trends within the framework of various projects is explained by the necessity of optimizing their participation in serving the needs of national and international economy as well as using the tools of environmental policy promotion. The subject of the research is the activity of institutional investors in contemporary environment and possible ways of making them as financial intermediaries more effective in providing the needs of the modern economy, especially in the fuel and energy complex as a key sector of the Russian Economy. The article provides a comparative analysis of the current set of factors and threats that affect the prospects of participation of institutional investors in financial markets. The complex analysis methodology, used in assessing the problems, involves considering the standpoint of the influence of a set of factors, subdivided into internal and external. Internal factors include the national market conditions and environmental issues. External factors reflect the long-term impact of a potentially adverse or favorable impact on the course of projects implementation based on institutional investors' facility in spite of market turbulence, political sanctions or pandemic conditions.
\end{abstract}

\section{Introduction}

Modern institutional investors are defined as special financial institutions that manage savings in the interests of private investors, maintain an acceptable level of risk, with the intent of obtaining the maximum investment return, backed by the terms and conditions of an agreement.

Institutional investors comprise collective investment institutions, pension funds, and insurance companies.

Institutional investors participate in the process of direct (on their name) and indirect (as agents) financing and perform the following economic functions:

- they are responsible for the efficient distribution of financial resources among economic entities;

- accumulate savings of the population and reduce transaction costs;

- diversify risks and participate in the environment protection.

\footnotetext{
* Corresponding author: jiz4@yandex.ru
} 
The term "institutional investors" is interpreted in the Russian economic literature relatively broadly, and includes both non-deposit and deposit intermediaries. Some authors limit themselves in listing most financial intermediaries as institutional investors. At the same time experts of the Bank for International settlements define insurance companies, pension funds and various collective investment schemes as institutional investors. In a number of studies of Russian economists the institutional investors are considered as non-bank financial intermediaries who invest funds, accumulated in course of their activity, in financial market instruments in order to gain profit.

We believe that retail banks cannot be classified as classic institutional investors, since their activity is related to attracting deposits and placing them in loans, while institutional investors are mostly focused on long-term investments.

It is worthwhile mentioning that the term "collective investment" is also widely used in the Russian Federation and related to non-state pension funds and specialized companies. Sometimes, so called collective investors are involved in raising funds from a large number of individuals for their subsequent investment as institutional investors.

Thus, to define prospects and problems of institutional investors, it is important to clear up the issue of identity of the institutional investor and the institution of collective investment

\section{Methodology}

The research used the methods of comparative analysis, content analysis and complex analysis. The method of comparative analysis is used to determine the influence of institutional investors on contemporary economy and identify the role of institutional investors as participants of financial markets.

The content analysis method made it possible to assess the role of institutional investors as participants of the financial market and forecast trends of developments within the framework of implementing various projects. In general, the collected data allows us to understand the trends of economic and financial situation and form evaluative judgment about the problems and prospects for institutional investors (II) activity in contemporary environment. The complex analysis method is used to systematize a set of factors and threats that affect the prospects of II participation in financial markets. The complex analysis methodology involves considering the object of assessment from the standpoint of the influence on it of a set of factors, subdivided into internal and external. Internal environment factors include the national market conditions. External factors reflect the long-term impact of a potentially adverse or favorable impact on the course of projects implementation on the basis of institutional investors facility in spite of market turbulence, political sanctions or pandemic conditions.

\section{Results and discussion}

International practice often use the term "asset management industry". It is known that the subject of asset management can be property owners as well as professional managers. Moreover, the management object is private and clients funds. Thus, institutional investors as financial intermediaries, operate in the asset management industry. As a result, we can distinguish the following essential features of institutional investors:

- $\quad$ accumulation of funds of individual and corporate investors;

- $\quad$ accumulated resources management as a single portfolio;

- long-term portfolio investments in securities; 
Taking into consideration the mentioned features we come to conclusion, that insurance companies, pension funds (PF) and collective investment institutions (collective investments), endowment funds can be defined as Institutional investors.

Actually, we define the trends of slowing down the process of globalization of financial markets and growing cyber activity of the market.

Globalization was the key factor of the financial markets development for a definite period. Actually, we confess the new stage of its development - economic partnership of globalized environment, manifested in integration of financial instruments, market participants, regulatory authorities, securities trading mechanisms, and unification of rules and regulations.

Having a wide range of investment options, institutional investors, actually, do not limit themselves to financial assets available on domestic markets. The increasing efficiency of information technologies and the easing of regulatory restrictions have contributed to their global activity. The trend towards formation of a global investment environment and integration of national capital markets to the global context has accelerated investments in foreign assets and usually purchase securities, depositary receipts, shares of investment funds, derivative financial instruments.

It is worthwhile mentioning that PF operate in the national and international markets and invest up to $30 \%$ of their assets in international instruments and markets. Thus, we come to conclusion, that contemporary stage of market development accelerates the cross-border supply of services by institutional investors and gives way to life insurers and pension funds to attract funds and contribute to the sustainable economic development on the national and supranational level.

Actually, we consider, that the main trend manifest itself in developing the resource base of green projects requests improvement of production and environment protection base. For example, the International Energy Agency (IEA) estimates that prevention of major climate changes by reducing carbon emission, additional $\$ 500$ billion is required to be invested annually, in addition to the $\$ 10.5$ trillion of investments in 2010-2030. At the same time BP experts consider, that in the nearest future approximately two thousand hydroelectric power plants will operate worldwide. It is important for strategic development and planning.

Actually, institutional investors have accumulated a significant amount of capital and the variety of instruments, well known to financial professionals that can help to smooth out the consequences of a significant slowdown in global economic growth. Acceleration of II activity will be a positive trend that will contribute to sustainable development of the global economy.

Due to the flexibility and mobility (along with huge assets and other advantages), institutional investors play a significant role in the global financial architecture, that is confirmed by their cooperation with supranational structures, changes in the composition and direction of global capital flows and environmental policy measures which change the role of institutional investors in global economy, turning them into systemic financial institutions.

Analysis has proved that institutional investors control more than 80 percent of the US stock market capitalization. At the same time, private investors, implementing a policy of strategic investment of company assets, control only 10 percent of the UK market. The consequence of such kind of II participation in the market is a trend of their significant control over business and its financing.

We consider it both positive and negative. On the one hand, institutional investors provide companies with broad access to financing, which plays a huge role in modern economy. On the other hand, there is a trend of market monopolization and formation of unofficial cartel agreements due to operational control of different players in the same segment of the market by one group of investors. 


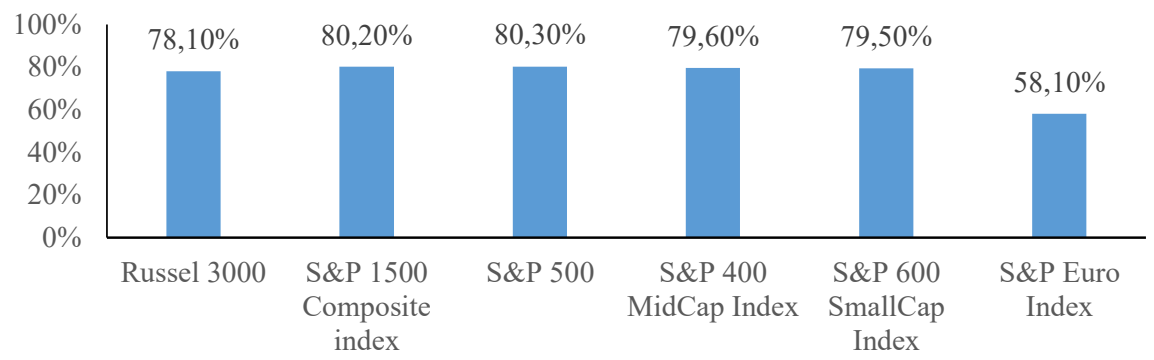

Fig. 1. Institutional investors ownership of the largest US stock indexes, Source: $80 \%$ of equity market cap held by institutions / / Pensions and Investment Magazine, 2019

It should also be noted that according to Bloomberg, different kind of institutions own more than 80 percent of the shares of the ten largest US companies.

Actually, investment funds control assets totaling more than \$ 18 trillion, which on average is about $24 \%$ of the GDP of the organization's member countries.

Pension funds and insurance companies control assets with a total value of 21.4 and 7 trillion US dollars ( $37 \%$ and $15 \%$ of GDP, respectively).

Table1. Investment funds assets in relation to GDP.

\begin{tabular}{|c|c|c|}
\hline Volume of assets in relation to GDP & 2009 & 2019 \\
\hline Austria & $44 \%$ & $45 \%$ \\
\hline Belgium & $24 \%$ & $38 \%$ \\
\hline Canada & $43 \%$ & $103 \%$ \\
\hline Chie & $0 \%$ & $0 \%$ \\
\hline Czeck Republic & $3 \%$ & $8 \%$ \\
\hline Danmark & $0 \%$ & $110 \%$ \\
\hline Estoni & $3 \%$ & $4 \%$ \\
\hline Finland & $23 \%$ & $54 \%$ \\
\hline France & $69 \%$ & $73 \%$ \\
\hline USA & $69 \%$ & $116 \%$ \\
\hline Russia & $1 \%$ & $3 \%$ \\
\hline
\end{tabular}

Calculated based on OECD data // https://stats.oecd.org/

Table 1 indicates the very little involvement of institutional investors in the economy of the Russian Federation. It seems appropriate to expand activity of pension funds, endowment funds and other specialized financial institutions - players in the financial market in order to use resources in solving strategic tasks.

As can be seen from the table above, the share of investment funds during $2009-2019$ significantly increased in many countries. The share of their assets greatly exceeds the GDP of some countries. Thus, we can conclude that the financial sector prevails in the economies of these countries.

The best value of this indicator is observed in the United States, which is due to the level of development of the stock market and the well-established tradition of personal savings for individuals.

The most popular investment tools for institutional investors are shares and units of various investment funds. It is important to note that in the period of $2009-2019$, the volume of assets placed in the mentioned tools exceeded the share of debt instruments such as corporate bonds and Federal loan bonds. Another important trend is the refusal of investors to increase placement of their funds with banks (deposits), caused by the difference of the interest rates of the banks and global financial market. 
Table 2. Value of assets of institutional investors in million US dollars.

\begin{tabular}{|c|c|c|}
\hline Asset value & 2009 & 2019 \\
\hline Deposits & 4181116 & 4450829 \\
\hline Debt instruments & 22329853 & 2323458 \\
\hline Loans & 3378084 & 3375834 \\
\hline Shares and units of investment funds & 21289707 & 24863143 \\
\hline
\end{tabular}

Calculated based on OECD data // https://stats.oecd.org/

The most attractive areas of investments is the infrastructure development. The most popular type of projects are the following.

Roads. The volume of investments amounted to more than 10 billion US dollars. The main forms of participation were concession agreements and investments through market infrastructure funds.

Airports. The volume of investments is about 1 billion US dollars with participation through infrastructure funds.

Gas transportation infrastructure in the United States, Mexico, and Australia. The volume of investments amounted to more than 20 billion US dollars. The main form of participation is investment through market infrastructure funds.

Investment in energy assets. The total volume of this category is about 1.5 billion US dollars. Participation is carried out by using debt financing, direct investments, as well as participation in market infrastructure funds.

Actually, we can distinguish the following classification of mutual funds in infrastructure financial market, depending on the structure (accumulation) of their assets, such as money market funds, bond funds, equity funds, mixed investment funds private equity funds, highrisk (venture) investment funds, fund of funds, rental funds, estate funds, mortgage funds, index funds (with index indication), credit funds, foundations of the commodity markets, hedge funds, foundations of artistic values, environment protection funds.

The UN set benchmarks in 2015 for achieving the 2030 Sustainable Development Goals, stating that they must "meet the requirements of the present without compromising the ability of future generations to meet their needs. For this, it is important to reconcile three pillars: economic growth, social inclusion and environmental protection. These elements are interrelated and critical to the well-being of individuals and society." [9].

Deterioration of the environment directly affects the quality of life of the population. Therefore, consumers began to vote with money in favor of goods that are produced in accordance with the principles of sustainable development. A March 2020 poll by the Capgemini Research Institute found that $79 \%$ of consumers change their shopping habits to reflect the impact of their purchases on social or environmental issues [1].

This kind of demand is converted into indicators that are significant for companies. Standard \& Poor's notes that from January 2010 to December 2019, the average monthly growth in the shares of companies with the lowest carbon dioxide emissions and accounting for $20 \%$ of the total number of companies in the MSCI World Index (developed markets) was 25 basis points higher than the $20 \%$ of companies in this Index with the worst such emission [2]. Bank of America Merrill Lynch found that firms with better ESG (environmental, social and governance) performance than their peers were more likely to turn into high-quality stocks, less likely to have significant price declines, and less likely to go bankrupt [3]. In addition, socially responsible companies have the opportunity to raise borrowed funds from banks at lower interest rates compared to companies with similar financial reliability that do not take ESG risks into account in their activities [4]. The cost of capital for companies that adhere to ESG principles is about $10 \%$ lower than for other companies, due to the fact that investors believe that they have lower risks in terms of noncompliance with environmental legislation [5].

The potential benefits of investing in projects implementing environmental protection 
programs are clear. Therefore, the analysis of possible risks associated with environmental pollution is very important, especially for large investment projects that provide for long payback periods and are typical for institutional investors, including portfolio investments of pension funds, national wealth funds, etc.

The topic of climate risks for portfolio and institutional investors, including sovereign funds, has become relevant only in the last 10-15 years. Moreover, in different parts of the world they are perceived differently. If earlier the main topic of the pre-project study was the financial analysis of the investment object, then in 2019 in Europe just over 50\% of investments were made taking into account the factors of sustainable development, and in the USA the share of such investments in stocks was about $25 \%$ [6].

Currently, the only generally accepted quantitative objectively verifiable indicator of environmental risk is the price of a ton of carbon dioxide emitted by an enterprise. Wherein, investors take into account in the financial analysis the possible costs of greenhouse emissions, regardless of whether such costs are incurred at the national level or not, because the regulatory rules can change quickly. When the project's products are exported, it is very likely that it will be additionally charged with a carbon tax, as already planned in the EU. The market estimates the cost of environmental pollution very high: for example, in the EU, where CO2 trading has been developing since 2005, the price per metric ton of CO2 in the European Emissions Trading System was above 60 euros at the beginning of September 2021 [10]. At the same time, hopes for taking into account the high absorptive capacity of the environment at the national level in the exporting country are not entirely justified, since the calculation of the future carbon tax in the EU will be carried out only taking into account the carbon neutrality measures of the enterprise exporting its products.

As you can see, measures to improve the climate significantly affect the efficiency of investments. On the other hand, as the Boston Consulting Group and the Global Financial Markets Association in their fundamental research on climate finance in December 2020 noted that while the need for financing climate projects around the world is 100-150 trillion US dollars, the role of institutional investors is very important: in the equity investments they provide it accounts for $35 \%$ of the total funding requirement, and in bonds - $21 \%$ [11].

High economic and political risks associated with sanctions pressure, the Russian Federation is on the path of economic development through substitution of European and American sources of financing, as well as optimization of domestic financial resources [7]. An important role in this regard is played by institutional investors who can participate effectively in the implementation of development programs.

According to our calculations, the public and private sectors invested about 5.7 trillion rubles (2019) in infrastructure development, which is 200 billion rubles (3.6\%) more than a year earlier. However, insurance companies and pension funds have no experience of participating in big projects, as a result, their share in capital investments is insignificant.

Investments in infrastructure remain attractive for private funds, but their money is getting into the industry too slowly. We consider, that the main reason is the lack of projects structured under bonds.

At the end of 2019, the share of corporate bonds in the investment portfolio of national private funds (NPF) decreased by 6 percentage points, to $45 \%$ (1.2 trillion rubles), while the share of Federal loan bonds (OFZ) increased sharply to $28 \%$ ( 0.7 trillion rubles), from $10 \%$ in the first half of the year. In monetary terms, NPF investments in Russian OFZs more than tripled, from 235 billion rubles to 739 billion rubles. Thus we can conclude, that the activity of private investment funds should be supported by public authorities, if the invest in social or industrial sector.

VEB (Vnesheconombank of the Russian Federation) since 2003 has been a state management company for the trust management of pension savings and since 2012 VEB performs the functions of a state management company for the funds of the payment reserve. 
VEB's activity is carried out in accordance with the legislation of the Russian Federation, regulatory legal acts of the President and Government of the Russian Federation, regulatory documents of the Central Bank of the Russian Federation, the Ministry of Finance of the Russian Federation, and other Federal Executive authorities. Observing the absolute priority of the interests of insured citizens, VEB invests pension savings in order to ensure their growth with a minimum level of risk.

Up to date VEB manages the funds of about 39 million future pensioners. A state-owned management company invests in government securities, international bonds, deposits, etc.

Isn't it limited? We consider infrastructure bonds to be of an interest to public authorities in contemporary economic environment.

Currently, there are about 58 non-state pension funds operating in Russia: 36 funds carry out mandatory pension insurance and 18 funds ( 2.6 trillion rubles).

The allocation of pension reserves and investment of pension savings are based on the following principles: •

- $\quad$ ensuring the safety of the funds;

- $\quad$ ensuring profitability, diversification and liquidity of investment portfolios;

- defining an investment strategy based on objective criteria that can be quantified;

- $\quad$ accounting for the reliability of securities;

- information openness of the process

- $\quad$ professional management of the investment process and their control.

We consider that pension funds can contribute greatly to the implementation of the environment protection policy by developing financial instruments for sustainable development.

In a contrast to developed countries pension savings legislation in Russia strictly defines the procedure of investment.

Russian clients usually choose conservative strategies, the yield of which is less volatile. More than half of investments are accumulated in Russian bonds [8]. However, over the past two years, shareholders ' appetite for risk has increased - the shares of equity and mixed investment funds assets have increased significantly due to net inflows, as well as outperforming returns from investing in shares.

A significant amount of investment by pension funds is concentrated in the Russian oil and gas sector. For example, last year two large associations of private funds were completed: in the middle of the year, three NPFs that fell within the perimeter of the Bank "FC OTKRITIE "merged on the basis of "LUKOIL-Garant" (now NPF "OTKRITIE"), and at the end of the year "Consent OPS" and "Neftegarant NGO"joined the Fund "Neftegarant". OTKRITIE NPF with assets at the beginning of this year of 565 billion rubles occupied the second place, but in the first quarter it fell to the third place (market assets decreased to 556 billion rubles), losing to Gazfond Pension savings (563.7 billion rubles). NPF Neftegarant took the ninth place (205.6 billion rubles).

The Association of private funds has also continued its activity. In the first quarter, NPF Safmar was joined by the Trust Fund. As a result, the unified Fund (264.7 billion rubles of assets) in the first three months of the year came in sixth place, ahead of NPF "Future" (256.5 billion rubles). as a result the concentration of the top 10 Russian private funds exceeded $90 \%$ of the reserves and savings market. The Russian financial market has long been living in a phase of oligopoly. At the beginning of last year, the top 10 players had more than $92.4 \%$ of all pension savings. Actually, this figure is 2.6 percentage points higher. The non-state pension provision (NGO) market is more diversified, but it is also approaching an oligopolistic one. At the beginning of the year, the ten largest players concentrated $89.5 \%$ of all pension reserves.

These examples vividly depicts volatility of the Russian financial market and the tendency of oligopolistic accumulation economic capital of institutional investors as 
participants of financial markets in strategic sectors of the national economy. At the same time, there is a variety of types of II and their instruments which can contribute to the sustainable development of the national economy. International experience in this regard is presented above.

\section{Conclusions}

The results obtained allowed us to draw the following conclusions. There are several trends for institutional investors activity in the financial market. Such as growing competition; passive portfolio management strategies with the predominance of active strategies and demand for new investment instruments to form securities portfolio.

The trend of growing competition is supported by increasing regulation requirements for the volume of funds and structure of assets, as well as the constant growth in the number of mutual funds, offering similar services to the population. At the same time the development of passive strategies is a logical result of continuation.

There are also some specific challenges for each type of institutional investors that are determined by market activity of insurance companies, non-state pension funds, and collective investment institutions. Main challenge for the insurance companies is the reduction of insurance schemes (tax optimization) and non-state pension funds activity. As one of the elements of scientific foresight, forecasting allows you to display possible scenarios for the development of institutional investors in Russia. Current market environment has proved, that the authorities are not interested in the development of domestic non-bank financial intermediaries, that prevents from transforming savings to investments.

Actually, the activity of institutional investors in the Russian financial market is insignificant. The main share of investments is accumulated by the Federal loan bonds and deposits in leading Russian banks. At the same time, based on the analysis of investment strategies and market behavior of key players, we can conclude about passive investment strategies in the Russian financial market. All of the above do not contribute to increasing the role of indirect financing.

It is important to take the following measures, which contribute to sustainable economic growth:

- improve taxation of insurance companies, requirements for the structure of the insurance company's investment portfolio and legislation by creating a unified code of responsible investments;

- $\quad$ promote cooperation between insurance and management companies, as well as increase information transparency of non-state investment funds.

- clarify the rights of depositors and participants in non-state investment funds while using corporate pension programs.

The above mentioned measures contribute to the resources to support national programs for sustainable economic development and environment protection.

\section{References}

1. K. Jacobs, J. Robey, K. van Beaumont, C. Lago, M. Rietra, S. Hewett, J. Buvat, N. Manchanda, S. Cherian, Capgemini Research Institute, 6 (2020)

2. R. Falk, K. Wang, T. Morris, E. Chan, S\&P Global. Market Intelligence, 5 (2020)

3. S. Subramanian, M. Kabra, S. Chopra, P. Strzelinska, L. Huang, ESG Matters - Global. ESG from A to Z: a global primer. Bank of America Merrill Lynch, 5 (2019)

4. O. Kordsachia, Review of Managerial Science (2020) 
5. S. Bernow, R. Nuttall, S. Brown, McKinsey, 3 (2020)

6. R. Eccles, Harvard Business Review IdeaCast, 663, https://hbr.org

7. R. Brayley, S. Myers, Principles of corporate Finance, 1008 (2016)

8. E. I. Shokhin, Financial management, 480 (2017)

9. The Sustainable Development Agenda. What is sustainable development? United Nations. https://www.un.org

10. Daily Carbon Prices, https://ember-climate.org/data/carbon-price-viewer/

11. Climate Finance Markets and the Real Economy. Boston Consulting Group and the Global Financial Market Association, 178 (2020) 